\section{(C) OPEN ACCESS}

\title{
Primary mucosa-associated lymphoid tissue (MALT) lymphoma of the gallbladder and review of the literature
}

\author{
Munenori Honda, ${ }^{1,2}$ Yoki Furuta, ${ }^{2,3}$ Hideaki Naoe, ${ }_{1}^{3}$ Yutaka Sasaki ${ }^{3}$
}

\begin{abstract}
${ }^{1}$ Department of
Gastroenterology and Hepatology, Kumamoto General Hospital, Yatsushiro, Japan

${ }^{2}$ Department of

Gastroenterology and Hepatology, Kokuho Minamata Shiritsu Sogo Iryo Center, Minamata, Japan

${ }^{3}$ Department of

Gastroenterology and Hepatology, Graduate School of Medical Sciences, Kumamoto University, Kumamoto, Japan
\end{abstract}

\section{Correspondence to} Dr Yutaka Sasaki M.D., Ph.D., sasakiy@kumamoto-u.ac.jp

Accepted 21 April 2017

\section{(D) croshark}

To cite: Honda M, Furuta $Y$, Naoe $\mathrm{H}$, et al. BMJ Case Rep Published Online First: [please include Day Month Year]. doi:10.1136/bcr-2017220161

\section{SUMMARY}

Mucosa-associated lymphoid tissue (MALT) lymphoma is rarely observed in the gallbladder, and its diagnosis before surgery is difficult. This report describes a case of primary MALT lymphoma of the gallbladder in an 80-year-old man. Imaging studies revealed a protruding lesion on the inside of the gallbladder, which led us to diagnose gallbladder carcinoma prior to the patient undergoing extended cholecystectomy. Microscopic examination of the resected specimen of the gallbladder demonstrated lymphoid follicles with atypical lymphocytes and the formation of lymphoepithelial lesions. These findings led to a final pathological diagnosis of primary MALT lymphoma of the gallbladder. The patient has been free of recurrence for 39 months after the surgery. Although precise diagnosis before the surgery was difficult in this case, preoperative examinations revealed a submucosal tumour-like lesion. MALT lymphomas should be considered when imaging findings are atypical for gallbladder carcinoma.

\section{BACKGROUND}

Although mucosa-associated lymphoid tissue (MALT) lymphoma occurs in various organs, primary MALT lymphoma in the gallbladder is extremely rare. Only 16 cases of primary MALT lymphoma in the gallbladder have been previously reported. Although preoperative diagnostic imaging examinations have yet to be established, preoperative ultrasonography (US) in this case revealed a submucosal tumour-like lesion, which is an atypical feature for gallbladder carcinoma. Thus, MALT lymphoma should be taken into consideration during the differential diagnosis of gallbladder tumours, especially when imaging examinations reveal atypical findings for gallbladder carcinoma, such as submucosal tumour-like lesions.

\section{CASE PRESENTATION}

An 80-year-old man with no significant medical history was admitted to our hospital for treatment of cholelithiasis. During hospitalisation, US demonstrated thickening of the gallbladder wall $(2 \mathrm{~mm}$, figure 1A). After the endoscopic treatment for the cholelithiasis, contrast-enhanced CT (CECT) was performed. A thickened wall was also observed by CECT, with homogeneous enhancement shown on the arterial, portal and delayed phases. Based on these imaging findings, there was no clear evidence to diagnose the lesion as a malignant tumour. Thus, the patient was examined by US at approximately every 4 months, with the examinations showing no significant changes in the size for 8 months. After 12 months, however, US revealed a $20 \mathrm{~mm}$ mass in the gallbladder with a smooth inner surface and which included a small hypoechoic homogeneous lesion inside (figure 1B). The mass lesion was $25 \mathrm{~mm}$ in diameter and exhibited homogeneous enhancement in the arterial, portal and delayed phase in CECT (figure 1C). MRI depicted the gallbladder mass with an isointensity relative to the liver parenchyma on the T1-weighted and T2-weighted images. Diffusion-weighted images showed heterogeneous hyperintensity of the tumour. Positron emission tomography (PET) indicated that there was a local abnormal uptake without distant metastasis. In addition, US demonstrated there was disruption of the structure of the gallbladder wall, while CECT showed laminar enhancement on the liver bed, which indicated invasion of the hepatic bed. The tumour invasion of the hepatic bed was difficult to detect when using PET.

\section{INVESTIGATIONS}

As the US images revealed a rapid increase of the mass over a year, it was strongly suspected the mass was a malignant tumour. CECT and MRI were performed for qualitative diagnosis and to assess the local invasion and distant metastasis. PET was also performed to help more precisely detect the distant metastasis. Although a definitive diagnosis cannot be made without a histological study, performing biopsies or cytological diagnoses can lead to complications, such as bleeding, dissemination and so on. Therefore, we formed our working diagnosis based on a series of radiological studies.

\section{DIFFERENTIAL DIAGNOSIS}

Using the radiological findings, we diagnosed malignant tumour of the gallbladder. Since adenocarcinoma accounts for $98 \%$ of all gallbladder malignant neoplasms, gallbladder tumours tend to be diagnosed as adenocarcinoma. While in rare cases the differential diagnosis needs to include malignant lymphoma, neuroendocrine carcinoma and carcinosarcoma, it can be difficult to distinguish these tumours clinically. 

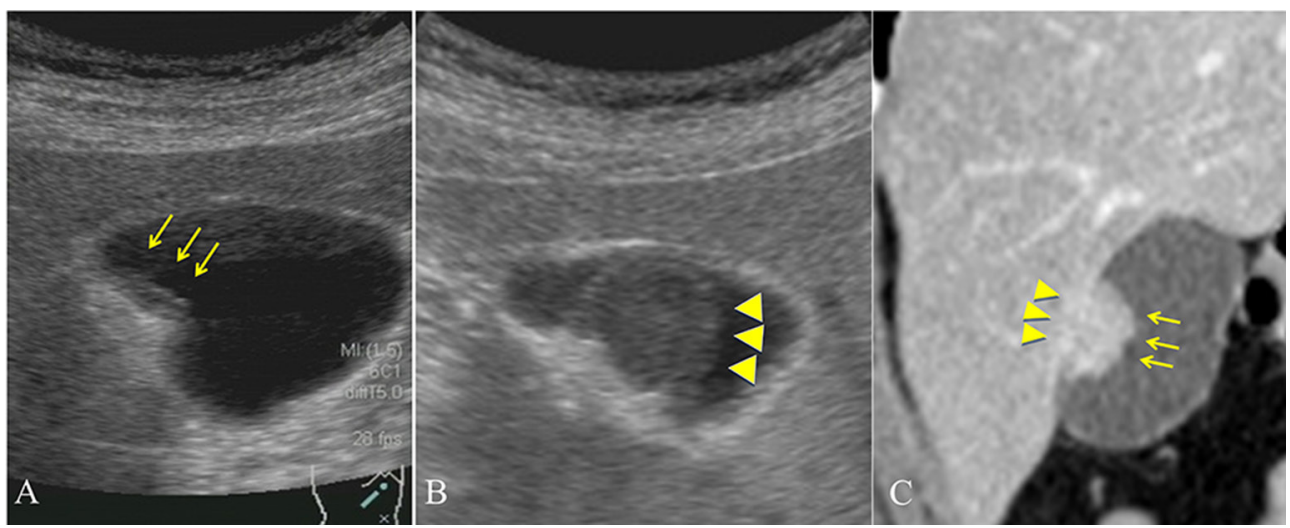

Figure 1 Imaging test. (A) US showing the thickening of the gallbladder wall (arrows). (B) Image from 12 months later shows a hypoechoic homogeneous lesion (arrowheads), and the lesion is covered by a smooth surface, which indicates a submucosal tumour-like lesion of the gallbladder. (C) CECT showing the mass lesion (arrows) and the laminar enhancement on the liver bed (arrowheads). CECT, contrast-enhanced CT; US, ultrasonography.

\section{TREATMENT}

The radiological findings for the current patient led to our diagnosis of a malignant tumour of the gallbladder. Since these findings specifically suggested gallbladder carcinoma, with suspected direct hepatic invasion and no distant metastasis, we performed extended cholecystectomy in the patient.

\section{OUTCOME AND FOLLOW-UP}

The resected gallbladder contained no gallstones, and the tumour size was $2.5 \times 2.0 \mathrm{~cm}$ in diameter. The inner surface of the tumour was smooth and covered with normal mucosa, which indicated a submucosal tumour (figure 2). Histopathological findings demonstrated lymphoid follicles with atypical lymphocytes that infiltrated all layers of the gallbladder wall and invaded into the hepatic bed (data not shown). The edge of the resected tissue was free from tumour cells. The pathological findings contained lymphoepithelial lesions, reactive follicles, monocytoid B cells, small lymphocytes and plasma cells (figure 3A). The immunohistochemistry study demonstrated that the lymphoid cells were positive for CD20 and $\mathrm{Bcl}-2$ (figure $3 \mathrm{~B}$ ) and negative for CD5, CD3, AE1/AE3, Bcl-6 and cyclin D-1 (data not shown). Based on these findings, the final pathological diagnosis was MALT lymphoma of the gallbladder. There has been no recurrence for 39 months, and the patient has not undergone any adjuvant chemotherapy after the surgery.

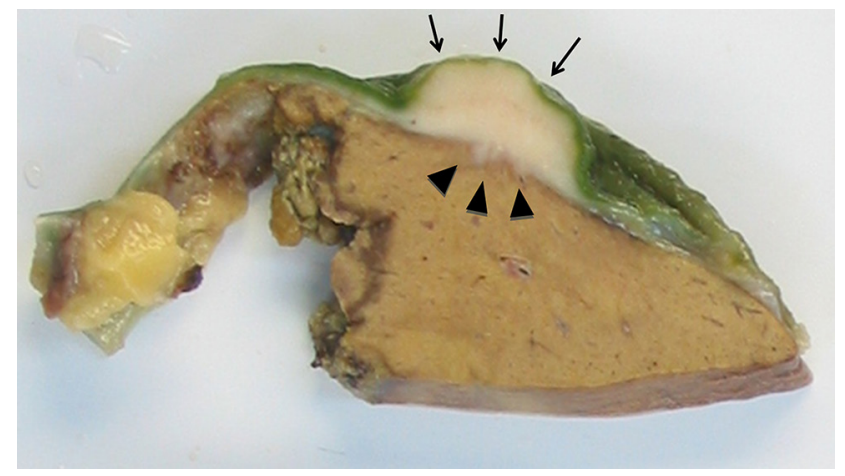

Figure 2 Macroscopic finding of the resected gallbladder. Note the regular mucosal surface (arrows) and the invasion into the hepatic bed (arrowheads).

\section{DISCUSSION}

MALT lymphoma occurs in various organs and is commonly found in the gastrointestinal tract, lungs, salivary glands, orbits, skin, thyroid gland and mammary gland. However, involvement of the gallbladder is rare. Adenocarcinoma accounts for $98 \%$ of the gallbladder malignancies, while malignant lymphoma is reported in only $0.1 \%-0.2 \%$ of these patients. The most common subtype among the gallbladder lymphomas is MALT lymphoma, which represents about $40 \%$ of these cases. ${ }^{12}$

As lymphoid tissue does not generally exist in the gallbladder, there are two possible mechanisms that could explain how MALT lymphoma develops. First, the occurrence may be secondary to chronic cholelithiasis or a bacterial infection. If there is chronic inflammation, this might cause lymphocyte infiltration into the gallbladder, thereby resulting in secondary follicle formation. Second, antigenic stimulation causes chromosomal translocation, which results in the synthesis of a fusion protein, API2MALT1. Since this protein stimulates apoptotic inhibitor genes via nuclear factor kappa-light-chain-enhancer of activated $B$ cells (NF- $\mathrm{KB}$ ) signalling, MALT lymphoma can proliferate independently from antigen stimulation. ${ }^{3}$ In fact, it has been previously reported that a gallbladder MALT lymphoma with API2MALT1 was found in one case. ${ }^{4}$ Even so, fluorescent in situ hybridization (FISH) analysis did not detect the API2-MALT1 fusion in this case. However, since our patient had been previously treated for choledocholithiasis and cholangitis, mechanical irritation or infection of his gallbladder could have occurred and led to the development of the MALT lymphoma.

To the best of our knowledge only 16 cases of MALT lymphoma arising in the gallbladder have been reported in the literature (table 1). ${ }^{2-17}$ In all of these cases, including our own case, MALT lymphoma of the gallbladder has been shown to be dominant in females (65\%), with the patient age ranging from 31 to 84 years (median, 74 years). The most common presenting symptoms were right upper abdominal pain and nausea/vomiting. Furthermore, cholecystolithiasis was found in two-thirds of the cases $(11 / 17)$.

It is very difficult to diagnose primary MALT lymphoma of the gallbladder prior to surgery. In fact, all of the previously reported cases were initially suspected as being gallbladder carcinoma or cholecystitis, with a final diagnosis only made by the pathological examination conducted after the surgery. The radiological features of gallbladder lymphoma vary among the reported cases. 


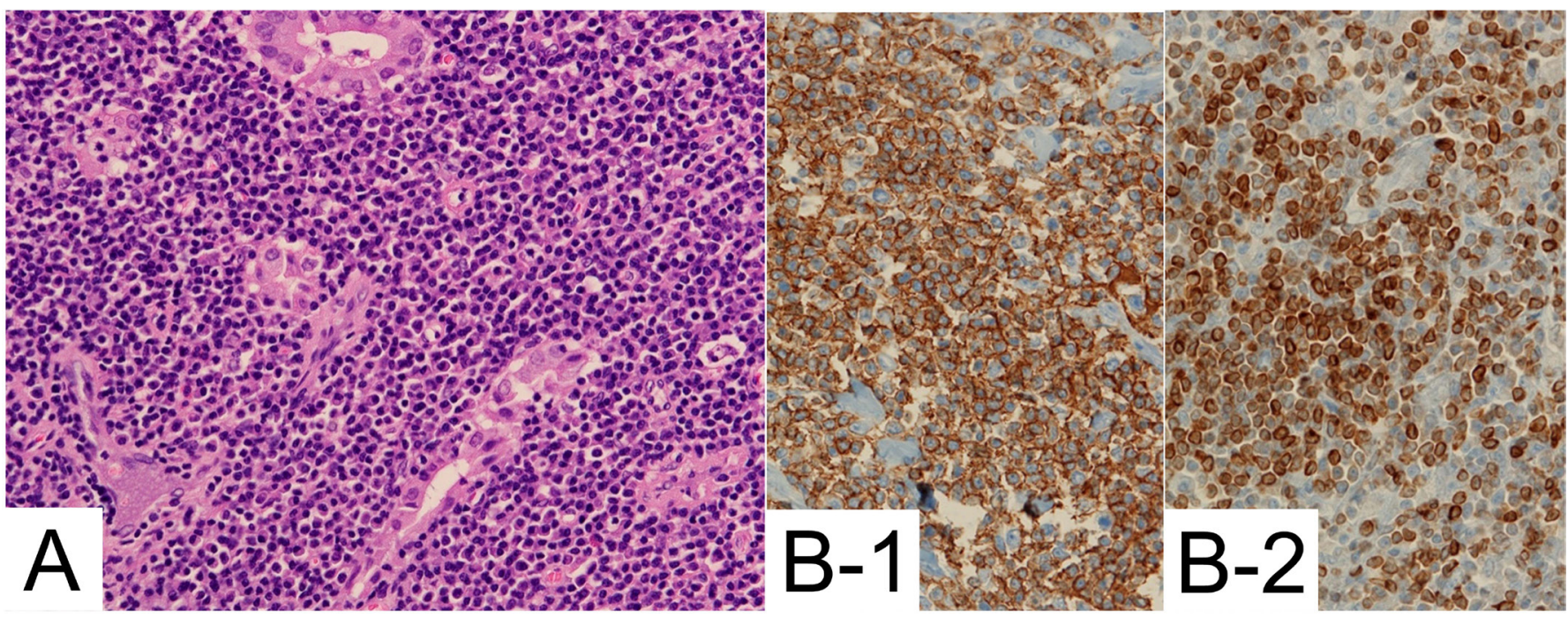

Figure 3 (A) Microphotograph showing the dense infiltrate of lymphoid cells and the formation of lymphoepithelial lesions. (B) Immunohistochemistry is positive for $\mathrm{CD} 20$ (1) and Bcl-2(2).

A few of these cases have referred to MR findings in which the gallbladder lesions were shown to be a low signal intensity on the fat-suppressed T1-weighted sequences and a high signal intensity on the fat-suppressed T2-weighted sequences, as compared with that observed for the liver parenchyma. ${ }^{18}$ In the present case, the US revealed the presence of a hypoechoic homogeneous lesion with a smooth surface, indicating the presence submucosal-like tumour of the gallbladder, which appears to be a unique feature of this tumour. Other previous cases have also reported finding atypical lymphocytes homogeneously infiltrated into the submucosal layer of the gallbladder wall in pathological specimens, with intact mucosal surface. Thus, this unique imaging finding appears to be useful for diagnosing MALT lymphoma of the gallbladder.

MALT lymphoma is one of the low-grade B-cell non-Hodgkin's lymphomas and slow-growing cancers. The treatment depends on the primary lesion of the MALT lymphoma. In gastric MALT lymphoma, standard treatments have already been established, with the aim of the initial treatment to eradicate Helicobacter pylori. On successful eradication, $70 \%-80 \%$ of the patients exhibit a complete remission..$^{19}$ However, cases that are resistant to the eradication require other treatments such as radiotherapy or chemotherapy. These alternate treatments have proven to be very effective for the gastric MALT lymphoma. In

\begin{tabular}{|c|c|c|c|c|c|c|c|c|}
\hline No & Age & Sex & Symptoms & Stone & Radiological findings & Treatment & Prognosis & Reference \\
\hline 1 & 80 & $M$ & - & No & Fairly nodular proliferation & - & Death from other causes & Pelstring et $a l^{5}$ \\
\hline 2 & 60 & $\mathrm{~F}$ & $\begin{array}{l}\text { RUQ pain, fever, nausea } \\
\text { and vomiting }\end{array}$ & Yes & Distended and thin & Cholecystectomy & NED at 6 months & Mosnier et al ${ }^{6}$ \\
\hline 3 & 75 & $\mathrm{~F}$ & $\begin{array}{l}\text { RUQ pain, nausea and } \\
\text { vomiting }\end{array}$ & Yes & Mass & Cholecystectomy & NED at 12 months & McCluggage et al \\
\hline 4 & 82 & M & $\begin{array}{l}\text { Jaundice and abdominal } \\
\text { pain }\end{array}$ & Yes & Wall thickening & Cholecystectomy & Death from other causes & Abe et $a l^{8}$ \\
\hline 5 & 74 & $\mathrm{~F}$ & RUQ pain and nausea & Yes & - & - & - & Bickel et $a l^{9}$ \\
\hline 6 & 58 & $\mathrm{~F}$ & Abdominal pain & No & Polypoid lesions & Cholecystectomy & NED at 24 months & Tsuchiya et al ${ }^{10}$ \\
\hline 7 & 65 & $\mathrm{~F}$ & RUQ pain & No & No particular & $\begin{array}{l}\text { Cholecystectomy } \\
\text { (chemotherapy) }\end{array}$ & $\begin{array}{l}\text { NED at } 96 \text { months } \\
\text { (recurrence in stomach) }\end{array}$ & Chim et $a l^{11}$ \\
\hline 8 & 31 & $\mathrm{~F}$ & RUQ pain & No & Wall thickening & Cholecystectomy & - & Rajesh et al ${ }^{12}$ \\
\hline 9 & 60 & $\mathrm{~F}$ & $\begin{array}{l}\text { Abnormal liver function } \\
\text { tests }\end{array}$ & Yes & - & Cholecystectomy & NED at 3 months & $\mathrm{Ng}$ et $\mathrm{al} \mathrm{I}^{13}$ \\
\hline 10 & 51 & $\mathrm{~F}$ & RUQ pain & Yes & - & Cholecystectomy & NED at 2 months & Koshy et $a l^{2}$ \\
\hline 11 & 75 & $\mathrm{~F}$ & RUQ pain & Yes & Wall thickening & Cholecystectomy & NED at 16 months & Bisig et al ${ }^{4}$ \\
\hline 12 & 78 & M & Nothing & No & Polypoid lesion & Cholecystectomy & NED at 3 months & Gardini et $a l^{14}$ \\
\hline 13 & 74 & M & - & Yes & - & - & - & Mani et $a l^{15}$ \\
\hline 14 & 84 & $\mathrm{~F}$ & - & No & - & - & - & Mani et $a l^{15}$ \\
\hline 15 & 65 & $\mathrm{~F}$ & RUQ pain and nausea & Yes & Polypoid lesion & Cholecystectomy & NED at 3 months & Bagwan et al ${ }^{16}$ \\
\hline 16 & 73 & M & $\begin{array}{l}\text { Abdominal pain } \\
\text { distension }\end{array}$ & Yes & Wall thickening & $\begin{array}{l}\text { Laparoscopic } \\
\text { cholecystectomy }\end{array}$ & NED at 12 months & Mitra et $a l^{17}$ \\
\hline 17 & 80 & $M$ & RUQ pain & Yes & Mass & Cholecystectomy & NED at 39 months & Present case \\
\hline
\end{tabular}

F, female; M, male; MALT, mucosa-associated lymphoid tissue; NED, no evidence of disease; RUQ, right upper quadrant. 
contrast, the management of MALT lymphoma arising from the gallbladder has yet to be established. Surgery is the most common treatment, as it results in good local control and prognosis. So far, there have been no reported deaths related to gallbladder MALT lymphoma after patients were treated surgically. Among the 16 reported cases, there has only been one case in which recurrence was observed. In this case, the relapse was detected in the stomach at 5 years after the surgical resection of gallbladder and required chemotherapy treatment. ${ }^{11}$ For follicular lymphoma, which is one of the low-grade B-cell lymphomas that are classified within the same category as the MALT lymphoma, watchful waiting is one of the therapeutic options, provided the tumour is growing very slowly and not causing any problems. However, in our case, the gallbladder lesion rapidly increased in size and invaded into the hepatic bed within a year. The patient was treated with cholecystectomy only and appears to have a good prognosis. Our current findings suggest that it is better to surgically treat cases as quickly as possible when gallbladder MALT lymphoma is suspected, with a cholecystectomy leading to a good prognosis for the patient.

\section{Learning points}

- Primary mucosa-associated lymphoid tissue (MALT) lymphoma in gallbladder is an extremely rare disease, and the diagnosis before surgery is difficult.

- Diagnosis of gallbladder MALT lymphoma should be considered when imaging findings and clinical presentation are atypical for gallbladder carcinoma, such as the presence of a submucosal tumour-like lesion.

- Local gallbladder MALT lymphomas can be managed by surgery, and recurrence is rare after complete excision.

Contributors $\mathrm{MH}$ performed the clinical examination and managed the patient and wrote the paper. YF performed the clinical examination and revised the manuscript. HN revised the manuscript. YS revised and conducted the manuscript. All authors discussed the results and implications and commented on the manuscript at all stages.

Competing interests None declared.

Patient consent Obtained.

Provenance and peer review Not commissioned; externally peer reviewed.

Open Access This is an Open Access article distributed in accordance with the Creative Commons Attribution Non Commercial (CC BY-NC 4.0) license, which permits others to distribute, remix, adapt, build upon this work non-commercially, and license their derivative works on different terms, provided the original work is properly cited and the use is non-commercial. See: http://creativecommons.org/ licenses/by-nc/4.0/

(c) BMJ Publishing Group Ltd (unless otherwise stated in the text of the article) 2017. All rights reserved. No commercial use is permitted unless otherwise expressly granted.

\section{REFERENCES}

1. Ono A, Tanoue $S$, Yamada $Y$, et al. Primary malignant lymphoma of the gallbladder: a case report and literature review. Br J Radio/ 2009:82:e15-19.

2 Koshy M, Zhao F, Garofalo MC. Primary MALT lymphoma of the gallbladder. Case report. J Gastrointestin Liver Dis 2008;17:207-10.

3 Bagwan IN, Ping B, Lavender L, et al. Incidental presentation of gall bladder MALT Iymphoma. J Gastrointest Cancer 2011:42:61-4.

4 Bisig B, Copie-Bergman C, Baia M, et al. Primary mucosa-associated lymphoid tissue lymphoma of the gallbladder: report of a case harboring API2/MALT1 gene fusion. Hum Pathol 2009:40:1504-9.

5 Pelstring RJ, Essell JH, Kurtin PJ, et al. Diversity of organ site involvement among malignant lymphomas of mucosa-associated tissues. Am J Clin Pathol 1991;96:738-45.

6 Mosnier JF, Brousse N, Sevestre C, et al. Primary low-grade B-cell lymphoma of the mucosa-associated lymphoid tissue arising in the gallbladder. Histopathology 1992;20:273-5

7 McCluggage WG, Mackel E, Mccusker G. Primary low grade malignant lymphoma of mucosa-associated lymphoid tissue of gallbladder. Histopathology 1996;29:285-7.

8 Abe Y, Takatsuki H, Okada Y, et al. Mucosa-associated lymphoid tissue type lymphoma of the gallbladder associated with acute myeloid leukemia. Intern Med 1999:38:442-4

9 Bickel A, Eitan A, Tsilman B, et al. Low-grade B cell lymphoma of mucosa-associated lymphoid tissue (MALT) arising in the gallbladder. Hepatogastroenterology 1999;46:1643-6.

10 Tsuchiya T, Shimokawa I, Higami Y, et al. Primary low-grade MALT lymphoma of the gallbladder. Pathol Int 2001;51:965-9.

11 Chim CS, Liang R, Loong F, et al. Primary mucosa-associated lymphoid tissue lymphoma of the gallbladder. Am J Med 2002;112:505-7.

12 Rajesh LS, Nada R, Yadav TD, et al. Primary low-grade B-cell lymphoma of the mucosa-associated lymphoid tissue of the gallbladder. Histopathology 2003;43:300-1

13 SK N, Epair K, Parsons S, et al. HP34P Extranodal marginal zone B-cell lymphoma of mucosa associated lymphoid tissue (MALT) type of the gallbladder. ANZ J Surg 2007;77:A47.

14 Gardini A, Saragoni L, La Barba G, et al. Simultaneous occurrence of primary diffuse large B-cell lymphoma and extranodal marginal zone (MALT) B-cell lymphoma in the gallbladder: a case report. Pathologica 2009;101:230-4

15 Mani H, Climent F, Colomo L, et al. Gall bladder and extrahepatic bile duct lymphomas: clinicopathological observations and biological implications. Am J Surg Pathol 2010;34:1277-86.

16 Bagwan IN, Ping B, Lavender L, et al. Incidental presentation of gall bladder MALT lymphoma. J Gastrointest Cancer 2011;42:61-4.

17 Mitra S, Mukherjee S, Chakraborty H. Mucosa associated lymphoid tissue lymphoma of gallbladder: a rare presentation. Indian J Pathol Microbiol 2014;57:502-35.

18 Yamamoto T, Kawanishi M, Yoshiba H, et al. Primary non-Hodgkin's lymphoma of the gallbladder. AJR Am J Roentgenol 2005;184:S86-7.

19 Thiede C, Morgner A, Alpen B, et al. What role does Helicobacter pylori eradication play in gastric MALT and gastric MALT Iymphoma? Gastroenterology 1997;113:S61-4.

Copyright 2017 BMJ Publishing Group. All rights reserved. For permission to reuse any of this content visit

http://group.bmj.com/group/rights-licensing/permissions.

BMJ Case Report Fellows may re-use this article for personal use and teaching without any further permission.

Become a Fellow of BMJ Case Reports today and you can:

Submit as many cases as you like

- Enjoy fast sympathetic peer review and rapid publication of accepted articles

- Access all the published articles

Re-use any of the published material for personal use and teaching without further permission

For information on Institutional Fellowships contact consortiasales@bmjgroup.com

Visit casereports.bmj.com for more articles like this and to become a Fellow 